\title{
Peran Kader Posyandu Pada Pelayanan Terpadu Wanita Prakonsepsi Di Wilayah Kerja Puskesmas Sapaya Kecamatan Bungaya Kabupaten Gowa
}

\author{
Role Cadre Posyandu Preconception Women In Integrated Services In The Area Of Work \\ Health Sapaya District Bungaya Gowa Regency \\ Puspita Rini ${ }^{1}$, Jemmi $^{2}$ \\ Akademi Kebidanan Graha Ananda Palu \\ Email : puspitarinie30@gmail.com
}

\begin{abstract}
Abstrak
Kader merupakan ujung tombak dalam kegiatan yang mendukung permasalahan kesehatan.Kader merupakan angggota masyarakat yang mau bekerja untuk menggerakkan masyarakat untuk menanggulangi masalah kesehatan. Tujuan penelitian adalah untuk mengetahui peran kader Posyandu dalam pelayanan terpadu wanita prakonsepsi. Jenis penelitian adalah kualitatif rancangan studi kasus (case study). Jumlah informan sebanyak 7 orang kader. Teknik yang digunakan adalah In-Depth Interview dan observasi. hasil penelitian menunjukan dalam mendapatkan informasi tentang warganya yang akan menikah, ada beberapa jalur yang dapat digunakan oleh kader yaitu kader dari TOMA atau pasanagan itu sendiri dan kader menjaring wanita prakonsepsi serta menjadi perantara petugas dimana kader mampu menjaring dan mendampingi wanita prakonsepsi sebanyak 6 orang (86\%). Disarankan agar lebih meningkatkan kepatuhan konsumsi kapsul multi zat gizi mikro wanita prakonsepsi, fungsi dari pengawas minum obat (PMO) perlu ditingkatkan serta Kader harus lebih berperan aktif dalam pemantauan dan pendampingan wanita prakonsepsi.
\end{abstract}

Kata Kunci: Peran Kader Posyandu, Pelayanan Terpadu Wanita Prakonsepsi

\begin{abstract}
adres are the spearhead in activities that support health problems. Cadres are members of the community who want to work to move the community to tackle health problems. The purpose of the study was to determine the role of Posyandu cadres in integrated pre-conception women's services. This type of research is a qualitative case study design (case study). The number of informants was 7 cadres. The technique used is In-Depth Interview and observation. The results of the study showed that in getting information about citizens who were going to get married, there were several pathways that could be used by cadres, namely cadres from TOMA or Pasanagan it self and cadres recruited preconceptions and became intermediaries where 6 cadres were able to recruit and accompany preconception women (86\%). It is recommended to further improve the adherence to the consumption of multi-micronutrient capsules for female consumption, the function of the supervisor for taking drugs (PMO) needs to be improved and cadres must play an active role in monitoring and mentoring preconception women.
\end{abstract}

Keywords: The Role of Posyandu Cadres, Pre-concept Women's Integrated Services 


\section{PENDAHULUAN}

Berdasarkan periode kritis tumbuh kembang janin manusia, muncul paradigma baru perbaikan kesehatan dan gizi dengan sasaran utama kaum wanita yang dimulai sejak prakonsepsi, yaitu sejak suatu keluarga merencanakan punya anak [1]. Oleh karena itu, program perbaikan gizi pada ibu harus dilakukan sejak prakonsepsi [1]. Namun, program perbaikan gizi dan pelayanan kesehatan di Puskesmas saat ini masih terbatas pada pelayanan kesehatan ibu dan anak (KIA).

Menurut data riskesdas tahun 2010 akses ibu hamil yang memeriksakan kehamilan dengan tenaga kesehatan pada trimester 1 (K1-trimester 1) adalah 72,3\%, kunjungan antenal 4 kali hanya 61,4\%, dan yang mengomsumsi 90 tablet besi hanya $18 \%$, keduanya jauh dari sasaran MDGs masing-masing 95\% dan 85\%. Di Sulawesi Selatan kunjungan K1 pada trimester pertama kehamilan hanya sebesar 62,7\% dan kunjungan K4 sebesar 44,5\%. Dan yang mengkonsumsi tablet besi sebanyak 90 tablet hanya 5,3\%. [2], [3]

Program pemberian tablet besi-folat juga belum dapat menyelesaikan masalah anemia. Menurut hasil Riset Kesehatan Dasar (Riskesdas) 2007, prevalensi anemia gizi ibu hamil di Indonesia sebesar 24,5\%, dan di Sulawesi Selatan 46,7\% [4]. Hal ini masih sangat besar khususnya yang terjadi di Sulawesi Selatan. Di Wilayah Kerja Puskesmas Sapaya Kecamatan Bungaya Kabupaten Gowa adalah sebesar 57,2\%.

Sejalan dengan upaya pemerintah untuk memperbaiki pelayanan kepada ibu hamil serta kualitas anak Indonesia, maka program pelayanan kepada ibu hamil perlu ditingkatkan. Program perbaikan gizi pada ibu hamil harus dipertajam dengan tujuan agar ibu hamil dapat terdeteksi sejak awal kehamilannya dan perbaikan gizi harus dimulai sejak prakonsepsi atau sejak menjadi pengantin.

Sumarmi (2009) telah mengembangkan sistem layanan terpadu pra nikah (LADUNI) di Kabupaten Gowa. Penelitian ini menghasilkan suatu model pelayanan terpadu pranikah yang melibatkan berbagai lembaga dan komponennya di masyarakat seperti KUA, Puskesmas, dan Desa / Kelurahan yang melibatkan Aparat Desa / Kelurahan, Petugas KUA Imam Desa / Kelurahan, Bidan Desa / Kelurahan, Kader Posyandu/PKK, PLKB. Berkaitan dengan hal di atas, saat ini tengah dilaksanakan penelitian payung tentang pelayanan terpadu pada wanita prakonsepsi (adaptasi model Sumarmi) oleh Otoluwa (2013), sebagai bagian dari penelitian tentang pengaruh pemberian suplemen multi zat gizi mikro kepada wanita prakonsepsi terhadap pencegahan kerusakan DNA ibu hamil. Sebagai bagian dari penelitian payung dimaksud, maka penelitian ini akan fokus pada peranan kader Posyandu. Peran kader sangat vital dalam meningkatkan akses masyarakat terhadap pelayanan kesehatan dan ini tidak cukup hanya bergantung pada tenaga kesehatan saja.Usaha peningkatan kesehatan masyarakat juga memerlukan bantuan kader kesehatan yang kompeten yang ada di masyarakat [5], [6].

Kader merupakan ujung tombak dalam kegiatan yang mendukung permasalahan kesehatan.Kader merupakan angggota masyarakat yang mau bekerja untuk menggerakkan masyarakat untuk menanggulangi masalah kesehatan.Karena kader berasal dari masyarakat itu sendiri, sehingga mereka mampu bergerak secara luas dan luwes [7].

Pelayanan terpadu wanita prakonsepsi (adaptasi model Sumarmi) sedang dilaksanakan di Wilayah Kerja Puskesmas Sapaya Kecamatan Bungaya Kabupaten Gowa . Kegiatan ini melibatkan Desa / Kelurahan, KUA, kader Posyandu / PKK, serta Puskesmas mulai dari pendaftaran calon pengantin, pemberian pelayanan kesehatan, serta kursus calon pengantin di KUA. Selain kepada calon pengantin program ini melibatkan pula mereka yang baru menikah pengantin baru.Untuk bisa mengakses pelayanan ini, peran kader sangat penting dalam menjaring wanita prakonsepsi, mendampingi, serta memonitor konsumsi kapsul multi zat gizi mikro yang diberikan sebagai bagian dari pelayanan 


\section{METODE}

Penelitian ini menggunakan metode penelitian kualitatif menggunakan pendekatan penelitian deskriptif untuk melihat gambaran akses pelayanan kesehatan dan kepatuhan konsumsi kapsul multi zat gizimikro wanita prakonsepsi menggunakan data sekunder dan penelitian kualitatif dengan rancangan studi kasus (case study) yang dimaksudkan untuk mengeksplorasi peran kader pada pelaksanaan pelayanan terpadu wanita prakonsepsi. Teknik yang digunakan adalah In-Depth Interview dan observasi. Populasi dalam penelitian ini adalah 7 orang Kader dan 7 orang wanita prakonsepsi di wilayah kerja Puskesmas Sapaya Kecamatan Bungaya Kabupaten Gowa. Sampel dalam penelitian ini adalah total dari jumlah yaitu sebanyak 7 orang kader dengan menggunakan tehnik pengambilan sampel purphosive sampling

\section{HASIL}

1. Bagaiamana kader mendapatkan informasi jika ada warga yang berada di wilayah kerjanya akan menikah

Berdasarkan hasil wawancara mendalam kepada informan (kader posyandu) dapat diketahui bagaimana cara kader mendapatkan informasi jika ada warga yang berada di wilayah kerjanya akan menikah. Sebanyak 6 dari 7 orang wanita prakonsepsi yang terjaring ke pelayanan terpadu diperoleh kader melalui koordinasi dengan imam Desa / Kelurahan. Hal ini sesuai dengan kutipan wawancara mendalam dengan kader sebagai berikut

“..., saya kerja sama dengan pak imam, kalau saya tidak tau, dia lagi yang tanya"

(Syr, 45 th)

Sebanyak 2 dari 7 wanita yang akan menikah diketahui kader dari wanita prakonsepsi sendiri yang mendatangi kader atas petunjuk dari imam Desa / Kelurahan pada saat diberikan surat pengantar pemeriksaan kesehatan "Dia disuruh pak imam datang dirumah untuk ditemani periksa"

Hal-hal tersebut di atas sesuai dengan apa yang disampaikan oleh imam Desa / Kelurahan dalam kutipan wawancara berikut :

"Sebenarnya kader kan sudah tau sebelumnya klo ada warganya yang mau menikah, cuma supaya lebih efektif saya hubungi kalo berkas catinnya smua sudah selesai sy hubungi kader ini ada wargata sudah siap untuk di bawa ke puskesmas, atau tapi ada kondisi lain sy langsung kasih tau saja catinnya ni surat pengantar pergiki dulu di puskesmas pergi sm kader untuk ditemani ke puskesmas"

(Znl, 55 th; Ihj, 53 th; Shd, 48 th)

2. Praktek kader dalam menjaring wanita prakonsepsi mendapatkan pelayanan kesehatan

Dari wawancara kader dan wanita prakonsepsi dapat diketahui bahwa ketika kader telah mendapatkan informasi ada warganya yang akan menikah, kader menjaring wanita prakonsepsi untuk mendapatkan pelayanan kesehatan di puskesmas dengan mengunjungi wanita prakonsepsi dan memberikan informasi dan menarik minat wanita prakonsepsi untuk melakukan pemeriksaan kesehatan di Puskesmas dengan menjelaskan kepada wanita prakonsepsi tentang manfaat pemeriksaan kesehatan bagi wanita prakonsepsi, seperti yang diungkapkan dalam kutipan wawancara berikut :

"saya datangi rumahnya dan memberikan pengarahan bahwa fungsi obat itu sangat bagus, saya sarankan jika mau cepat dapat keturunan sebaiknya kamu ikut program ini, kemudian diperiksa darahnya apakah ada masalah dalam darah atau bagaimana dan disarankan mengkonsumsi kapsul supaya mereka tertarik"

Hal tersebut dibenarkan oleh keterangan yang disampaikan oleh wanita prakonsepsi seperti yang disampaikan dalam hasil wawancara mendalam berikut: 
"iya datang ke rumah bilang ayo ke puskesmas mau suntik"

(Smn, 23 th)

Kader mengajak wanita prakonsepsi ke puskesmas dan memberikan pengertian kepada keluarganya agar memberikan izin kepada anaknya untuk melakukan pemeriksaan di Puskesmas, seperti apa yang diungkapkan oleh beberapa kader berikut

"kita ajak, kita kasih pengertian keluarganya tentang suntik TT karena di ibunya dia kira ini untuk KB"

(Rsm, 43)

Hasil menunjukkan bahwa dari 7 orang yang memenuhi kriteria wanita prakonsepsi yang dijaring oleh kader ke pelayanan terpadu sebesar $100 \%$ dan yang tidak dijaring sebanyak oleh kader sebesar $0 \%$.

Hal ini sesuai dengan apa yang disampaikan oleh Imam Desa / Kelurahan setempat :

" kalau ada yang mau menikah, saya selalu kasih pengantar ke puskesmas, tapi biasa yang tidak kesana yah mungkin karena malu ke sana karena sudah bermasalah, ada juga yang sudah tidak sempat kesana karena terlambat kasih masuk berkasnya, baru kalau dekat-dekat menikah tidak bolehmi keluar sama orang tuanya, ada juga yang sibuk kerja atau kuliah nantipi hari H nya baru dapat cuti kasian

(Znl, 55 th; Ihj, 53 th; Shd, 48 th)

Kader telah mengetahui tempat pemeriksaan untuk wanita prakonsepsi sehingga kader mengantar langsung kepada Bidan yang bertugas dan menyampaikan kepada petugas agar memberikan pelayanan kesehatan kepada warganya, karena terdapat beberapa wanita prakonsepsi yang salah masuk ruang pemeriksaan mereka masuk ke ruang Poli Umum dan menurut kader, wanita prakonsepsi perlu untuk didampingi oleh kader ke puskesmas untuk mendapatkan pelayanan kesehatan calon pengantin karena mereka jarang berkontak dengan puskesmas dan merasa tidak percaya diri jika harus pergi sendiri, seperti yang di ungkapkan oleh beberapa kader berikut :

"Iya, tapi baru satu orang itu saya dampingi karena biasakan saya suruh sendiri bilang kesanami, Saya antar langsung ke bidan wahida........"

(Hsn, 45 th)

Namun ada beberapa wanita prakonsepsi yang tidak didampingi oleh kader, wanita prakonsepsi dapat didampingi oleh keluarga, calon suami atau Ketua RW yang mengurus kelengkapan berkas pernikahan wanita prakonsepsi, hal ini diketahui dari hasil wawancara kader dan wanita prakonsepsi serta hasil observasi berikut :

"Pada saat pemeriksaan kedua saya kerumahnya sym saya suruh ke puskesmas duluan saya bilang nanti ketemu di puskesmas, kalau yang pertama bukan saya yang antar"

(Msn, 42 th)

Hal ini di atas menunjukkan bahwa wanita prakonsepsi perlu didampingi baik itu keluarga ataupun kader karena mereka jarang berkontak dengan puskesmas dan wanita prakonsepsi takut untuk suntik TT dan diambil darahnya, dan jika mereka didampingi mereka dapat dimotivasi oleh kader atau keluarga yang mendampingi agar tidak takut pada saat suntik TT dan diambil darahnya.

Dari hasil wawancara kepada wanita prakonsepsi dan hasil observasi diketahui bahwa wanita prakonsepsi yang akan menikah sebagian besar telah mendapakan pelayanan kesehatan berupa pengukuran antropometri seperti pengukuran Tinggi Badan (TB), Berat Badan (BB), Lingkar lengan Atas (LILA), Lingkar Panggul (LIPA), Lingkar Pinggul (LIPI), pengukuran tekanan darah, pemberian suntik TT (tenanus toxoid) oleh Bidan, pemberian konseling gizi dan kapsul multi zat gizi mikro oleh petugas gizi, seperti yang diungkapkan oleh wanita prakonsepsi dalam hasil wawancara berikut:

“di puskesmas diukur berat badanku, tinggi badan, lingkar lengan, lingkar perut ditensi, disuntik, dikasih penyuluhan 
dikasih juga obat baru dibawa pergi periksa darah di prodia

(Frd24 th; Mrs, 27 th; Hkm, 31 th; Rmw,17 th; Smn, 23 th; Mhn, 25 th; Sym.26 th; Sar.26 th; Rng, 17; Md, 29 th)

3. Praktek kader dalam memantau konsumsi kapsul multi zat gizimikro wanita prakonsepsi

Dari hasil wawancara dan observasi diketahui bahwa kader posyandu memantau konsumsi kapsul wanita prakonsepsi dengan memberikan kapsul multi zat gizimikro kepada wanita prakonsepsi setiap minggu sesuai jadwal pemberian kapsul multi zat gizimikro, namun kader tidak mengecek lembar PMO sebagai indikator untuk mengontrol konsumsi kapsul multi zat gizi mikro wanita periode prakonsepsi setiap hari dalam 1 minggu,

"dia tidak periksa lembar warna pinknya karena saya jarang ketemu"

(Frd, 24 th)

Dari 7 orang wanita prakonsepsi yang di pantau oleh kader hanya 1 orang kader yang mengecek lembar PMO dari wanita prakonsepsi.

Kader mengontrol konsumsi kapsul dengan menanyakan langsung kepada wanita prakonsepsi apakah mereka mengkonsumsi kapsul, menanyakan keluhan wanita prakonsepsi mengkonsumsi kapsul dan juga memberikan motivasi dengan menjelaskan manfaat kapsul tersebut, seperti yang diungkapkan oleh kader dalam hasil wawancara mendalam berikut :

"saya selalu kerumahnya, atau itu (menunjuk anaknya) dan saya juga anjurkan, saya bilang apakah dia minum setiap malam?, saya bilang itu obat bagus bukan menjarangkan tapi menyuburkan"

(Hsy, 56 th)

Kader membawakan kapsul multi zat gizi mikro kepada wanita prakonsepsi setiap minggu sesuai jadwal pemberian kapsul multi zat gizi mikro, kader selalu mengingatkan wanita prakonsepsi minum kapsul dan memberi pesan kepada PMO agar secara rutin dan memberi pesan kepada PMO agar selalu mengingatkan wanita prakonsepsi minum Kapsul setiap malam seperti yang diungkapkan oleh kader dalam hasil wawancara mendalam berikut :

"Saya sering ke rumahnya, saya tanyakan itu "bagaimana sudah diminum obatnya?, sudah habismi obatnya diminum? Biasa saya tanya dia atau ibunya saya tanya"

(Syn, 38 th)

Kader tidak dapat memantau dengan baik konsumsi kapsul wanita prakonsepsi karena tidak pernah bertemu dengan wanita prakonsepsi pada setiap minggu kunjungan, sehingga kader memberikan dan mengontrol konsumsi kapsul wanita prakonsepsi melalui keluarganya yang juga bertindak sebagai PMO-nya, seperti yang diungkapkan oleh kader berikut :

"dengan memberi kartu control, dan bertanya langsung ke pengawas minum obatnya"

(Rml, 35 th)

4. Kendala dalam menjaring wanita prakonsepsi mendapatkan pelayanan kesehatan di Puskesmas

Kendala-kendala kader dalam menjaring wanita prakonsepsi ke puskesmas adalah Kader kadang tidak ada waktu atau sibuk dan wanita prakonsepsi juga bekerja pada pagi hari, seperti yang di sampaikan oleh kader dalam wawancara mendalam berikut

“...waktu tidak ada, si catinnya sendiri orang sibuk, ....."

(Rml, 35 th)

Kader sulit menentukan apakah wanita masih dalam prakonsepsi atau sudah konsepsi karena banyak yang sudah bermasalah, Beberapa wanita prakonsepsi dilarang oleh orang tua karena kurangnya pemahaman orang tua tentang pentingnya kesehatan prakonsepsi 
“..........bukan pengantinnya yang bermasalah tapi orang tuanya itu yang larang toh"

(Syr, 45 th)

5. Kendala dalam mendampingi wanita prakonsepsi mendapatkan pelayanan kesehatan di Puskesmas

Dalam mendampingi wanita prakonsepsi kader juga menemui beberapa kendala dilapangan seperti jika kader mengantar wanita prakonsepsi pagi-pagi ke puskesmas tetapi petugas belum ada sementara kader harus pergi bekerja

“......Biasa dari puskesmas yang menangani biasa tidak ada (belum datang) jadi kita menunggu sementara kita mau cepat-cepat"

(Syn, 43 th)

Keluarga wanita prakonsepsi tidak mengerti dan menyalahkan kader jika terjadi sesuatu pada anaknya sehingga kader trauma dan takut untuk mengantar wanita prakonsepsi ke puskesmas. Wanita prakonsepsi juga merasa tidak percaya diri dan takut ke puskesmas seperti yang diungkapkan oleh kader berikut

“........ada yang malu dan tidak pede ke puskesmas"

(Nhd, 38 th)

6. Kendala dalam memantau konsumsi kapsul multi zat gizi mikro wanita prakonsepsi

Wanita prakonsepsi tidak mau minum kapsul karena ada keluhan efek samping kapsul

"Terkadang catin kalau sudah minum obat banyak keluhan, jadi enggan minum karena keluhan...."

(Rml, 35 th)

Kader tidak dapat mengontrol dengan baik konsumsi kapsul wanita prakonsepsi karena pada saat kader membawakan kapsul kader tidak bertemu dengan wanita periode prakonsepsi

"Itu ji kalau saya bawakan obat dia tidak ada, terus dia ada saya tidak ada, jadi saya kasih saja drumahnya"

(Nhd, 38 th)

Kader juga tidak dapat memantau konsumsi kapsul karena lembar PMO wanita prakonsepsi tidak di simpan dengan baik. Wanita prakonsepsi dilarang oleh orang tua dan mengira itu obat KB

"....ada juga orang tuanya sendiri yang melarang untuk minum obat"

(Rml, 35 th)

\section{PEMBAHASAN}

1. Cara kader mendapatkan informasi warganya yang akan menikah

Dari hasil penelitian cara kader dalam mendapatkan informasi tentang warganya yang akan menikah ditunjukkan pada mekanisme di bawah ini :

Yang pertama yaitu kader melakukan koordinasi dengan imam Desa / Kelurahan dimana kader menyampaikan kepada Imam Desa / Kelurahan, agar imam Desa / Kelurahan menghubungi kader jika ada warganya yang melakukan registrasi nikah.

Pelayanan terpadu merupakan pelayanan yang melibatkan beberapa komponen dimana setiap komponen melakukan koordinasi dalam pelayanan wanita prakonsepsi, dalam mendapatkan informasi kader seharusnya berkoordinasi dengan Desa / Kelurahan atau imam Desa / Kelurahan untuk mengetahui warga yang akan menikah karena pendaftaran dan pengurusan berkas nikah di Kacamatan Bungaya dilaksanakan oleh imam Desa / Kelurahan sebagai Petugas Pencatat Nikah (PPN). 
Namun, beberapa kader tidak melakukan koordinasi dengan Imam Desa / Kelurahan, dimana terdapat 1 (satu) Desa / Kelurahan yang tidak mempunyai imam Desa / Kelurahan dan pengurusan berkas registrasi nikah dilakukan oleh ketua RW setempat, sehingga kader tidak melakukan koordinasi dengan Imam Desa / Kelurahan dan langsung mengetahui dari ketua RW yang juga merupakan suaminya dan beberapa kader juga bertindak sebagi ketua RT dimana warga yang akan menikah akan mengurus surat pengantar dari ketua RT sebelum melakukan registrasi nikah di Desa / Kelurahan ataupun di imam Desa / Kelurahan sehingga secara tidak langsung akan mendapatkan informasi warga yang menikah.

2. Peran Kader dalam penjaringan wanita prakonsepsi mendapatkan akses pelayanan kesehatan di Puskesmas

Jalur penjaringan wanita prakonsepsi oleh kader yang paling baik adalah kader menjaring melalui imam Desa / Kelurahan dimana kader dapat menjaring sebanyak 50\% wanita prakosepsi berdasarkan informasi dari Imam Desa / Kelurahan.

Setelah kader mendapatkan informasi warganya yang akan menikah, baik dari Imam Desa / Kelurahan, Ketua RW, masyarakat maupun dari wanita prakonsepsi itu sendiri, kader kemudian menjaring wanita prakonsepsi untuk mendapatkan pelayanan kesehatan.

Kader menjaring wanita prakonsepsi dengan mengunjungi wanita prakonsepsi dan memberikan informasi kepada wanita prakonsepsi atau keluarganya untuk melakukan pemeriksaan kesehatan di Puskesmas sebelum melakukan kursus calon pengantin (suscatin) di Kantor Urusan Agama. Hal ini sesuai dengan hasil penelitian Sulastyawati dkk ( 2007), yang menunjukkan bahwa kader kesehatan sebagai salah satu sumber informasi bagi masyarakat dimana kader kesehatan mempunyai bekal pengetahuan dan keterampilan untuk menyampaikan informasi dalam penyuluhan [8].

Selain memberikan informasi kader juga memberikan motivasi untuk menarik minat wanita prakonsepsi untuk melakukan pemeriksaan kesehatan di puskesmas dengan menjelaskan kepada wanita prakonsepsi dan atau keluarganya tentang manfaat pemeriksaan kesehatan bagi wanita prakonsepsi.

Pemanfaatan pelayanan kesehatan oleh masyarakat sangat ditentukan oleh dukungan tokoh masyarakat (TOMA) dan peran kader sebagai motor penggerak. Menurut Sarwono (2004) peran anggota masyarakat (kader) adalah sebagai motivator atau penyuluh kesehatan yang membantu para petugas kesehatan untuk meningkatkan kesadaran masyarakat tentang perlunya hidup sehat dan memotivasi mereka untuk melakukan tindakan pencegahan penyakit dengan menggunakan sarana kesehatan yang ada [9].

Dari 7 orang wanita prakonsepsi yang menikah pada bulan Jannuari - Februari, sebanyak 7 orang $(100 \%)$ telah terjaring ke pelayanan terpadu. Dari 7 orang (100\%) wanita prakonsepsi, sebanyak 6 orang (86\%) pulan yang dijaring oleh kader, 1 orang (14\%) yang tidak dijaring oleh kader dijaring pada saat registrasi di kantor lurah.

3. Peran Kader dalam pendampingan wanita prakonsepsi mendapatkan akses pelayanan kesehatan

Untuk wilayah Desa / Kelurahan Sapaya, Magempang dan Buakkang sistemnya adalah jika kader telah mendapatkan informasi tentang warganya yang akan menikah, kader mengunjungi warganya terse- 
but menyampaikan untuk melakukan pemeriksaan kesehatan di Puskesmas, dan jika wanita prakonsepsi telah mendapatkan surat pengantar dari Imam Desa / Kelurahan/ kantor lurah, maka kader menjemput wanita prakonsepsi untuk didampingi ke Puskesmas, atau wanita prakonsepsi yang mendatangi kader dirumahnya untuk didampingi ke puskesmas atas petunjuk dari imam Desa / Kelurahan.

Sedangkan untuk Desa / Kelurahan Bissoloro, berbeda dengan 3 Desa / Kelurahan lainnya, karena khusus untuk Desa / Kelurahan Bissoloro tidak memiliki Imam Desa / Kelurahan, sehingga jika ada warga yang menikah akan langsung melakukan registrasi di Kantor Lurah, dari Kantor Lurah wanita prakonsepsi diberikan surat pengantar ke Puskesmas (RW 2 dan 3), dan khusus untuk RW 1, ketua RW yang aktif menggantikan tugas Imam Desa / Kelurahan untuk wilayah kerjanya dan juga istrinya adalah kader sehingga jika ada warga yang menikah akan langsung disarankan untuk ke puskesmas, dan menanyakan kapan ada waktunya untuk didampingi ke Puskesmas.

Menurut Hanna dkk (2000), Kader merupakan penghubung yang handal antara petugas dengan masyarakat. Hafess dkk (2011) juga menemukan bahwa program pemberdayaan kader sebagai penghubung fasilitas kesehatan dengan masyarakat akan meningkatkan pemanfaatan pelayanan kesehatan dasar dimana dalam penelitian ini kader telah mampu mendampingi wanita prakonsepsi sebanyak 86\% [10], [11].

Hal ini di atas menunjukkan bahwa wanita prakonsepsi perlu didampingi baik itu keluarga ataupun kader karena mereka jarang berkontak dengan puskesmas dan wanita prakonsepsi takut untuk suntik TT dan diambil darahnya, dan jika mereka didampingi mereka dapat dimotivasi oleh kader atau keluarga yang mendampingi agar tidak takut pada saat suntik TT dan diambil darahnya.

4. Peran Kader dalam pemantauan konsumsi kapsul multi zat gizimikro untuk meningkatkan kepatuhan konsumsi kapsul multi zat gizimikro

Dalam mengkonsumsi kapsul multi zat gizimikro, setiap wanita prakonsepsi mempunyai pengawas minum obat (PMO), suami/ibu atau orang lain yang ditunjuk, kapsul dikonsumsi sekali sehari pada malam hari setelah selesai makan, Selesai kapsul dikonsumsi wanita prakonsepsi, pengawas minum obat diminta untuk mencontreng lembar kontrol yang telah disiapkan dan setiap kunjungan.

Peran kader adalah memberikan kapsul kepada wanita prakonsepsi dan kader mencatat jumlah kapsul yang dikonsumsi oleh wanita prakonsepsi minggu sebelumnya serta memberikan motivasi/ penyuluhan kepada wanita prakonsepsi untuk rutin dalam mengkonsumsi obat.

Dari hasil kader posyandu memantau konsumsi kapsul multi zatgizi mikro wanita prakonsepsi dengan melakukan kunjungan setiap minggu ke rumah wanita prakonsepsi; memberikan kapsul multi zat gizimikro kepada wanita prakonsepsi sebanyak 7 kapsul sesuai jadwal pemberian kapsul multi zat gizimikro; kader juga mengontrol konsumsi kapsul multi zat gizimikro wanita prakonsepsi dengan menanyakan langsung kepada wanita prakonsepsi apakah mereka mengkonsumsi kapsul dan beberapa kader mengontrol konsumsi kapsul multi zat gizimikro melalui Pengawas Minum Obat (PMO) jika tidak bertemu dengan wanita prakonsepsi. Namun kader tidak mengecek lembar PMO sebagai indikator untuk menilai kepatuhan wanita prakonsepsi dalam mengkonsumsi kapsul dan kader juga tidak mencatat 
jumlah konsumsi kapsul yang telah dikonsumsi pada lembar PMO untuk mengontrol konsumsi kapsul multi zat gizimikro wanita prakonsepsi setiap hari dalam 1 minggu.

Untuk meningkatkan kepatuhan wanita prakonsepsi dalam mengkonsumsi kapsul zat gizi mikro, kader memberikan informasi dan motivasi dengan menjelaskan manfaat kapsul tersebut, kader selalu mengingatkan wanita prakonsepsi minum kapsul secara rutin dan memberi pesan kepada PMO agar selalu mengingatkan wanita prakonsepsi minum Kapsul setiap malam. Hal ini didukung oleh penelitian yang dilakukan oleh Helmi dkk (2011) bahwa faktor pendorong/penguat kepatuhan adalah referensi dari kader dan dukungan sosial dari suami, anggota keluarga lainnya dan kader [12].

Belum terdapat penelitian yang melihat pengaruh pemantauan kader terhadap kepatuhan konsumsi kapsul wanita prakonsepsi. Menurut Hutabarat (2008), Faktor eksternal yang berhubungan dengan kepatuhan minum obat adalah dukungan keluarga dan dukungan petugas [13]. Hal ini didukung oleh pendapat Broek (2011) bahwa untuk meningkatkan kepatuhan konsumsi tablet Fe maka diperlukan sistem evaluasi dan monitoring yang dapat dipercaya [14].

Dalam penelitian yang telah ada sebelumnya adalah penelitian yang melihat peran kader dalam pemantauan konsumsi tablet Fe ibu hamil. Menurut penelitian yang telah dilakukan oleh Sipato (2012), ada hubungan yang signifikan antara kepatuhan mengkonsumsi tablet zat besi dan perubahan kadar $\mathrm{Hb}$ ibu hamil, Ibu hamil menjadi patuh mengkonsumsi tablet Fe karena mendapat motivasi dan dorongan dari kader masyarakat yang selalu mendampinginya dalam mengkonsumsi tablet zat besi selama sebulan. Kader masyarakat selalu memberikan arahan kepada ibu hamil bahwa mengkonsumsi tablet zat besi setiap hari sangat penting untuk dirinya dan janinnya [15].

Sebanyak 7 orang wanita prakonsepsi yang dipantau mengkonsumsi kapsul multi zat gizimikro oleh kader. Selama pemantauan oleh kader sebanyak 5 orang (71\%) yang patuh dan 2 orang (29\%) yang tidak patuh.

5. Kendala-kendala Kader dalam melaksanakan perannya pada pelayanan terpadu wanita prakonsepsi

Dari hasil penelitian, dalam menjaring dan mendampingi wanita prakonsepsi mendapatkan pelayanan kesehatan sebagian besar kader tidak mengalami kendala, namun ada beberapa kader yang mendapatkan kendala di lapangan.

Kendala-kendala kader dalam menjaring mendampingi wanita prakonsepsi ke puskesmas adalah Kader kadang tidak ada waktu atau sibuk hal ini dikarena selain melakukan kegiatan posyandu kader juga mempunyai aktivitas di luar posyandu dimana kader banyak difungsikan untuk melakukan pendataan di masyarakat, membantu kegiatan Desa / Kelurahan dan kecamatan dan kader mempunyai profesi sebagai guru dan pegawai honor.

Berdasarkan teori Green, salah satu faktor yang mempengaruhi peran kader adalah pekerjaan. Menurut Mantra (1983) menyatakan bahwa salah satu syarat untuk menjadi kader adalah mempunyai cukup waktu untuk masyarakat, jika kader mempunyai kesibukan bekerja maka waktu luang yang disediakan untuk kegiatan posyandu dapat sangat terbatas. Oleh karena itu, kader yang tidak bekerja cender- 
ung memiliki waktu luang yang lebih banyak dalam membantu posyandu dibandingkan dengan mereka yang bekerja [16].

Beberapa wanita prakonsepsi dilarang oleh orang tua karena kurangnya pemahaman orang tua tentang pentingnya kesehatan prakonsepsi, mereka menganggap bahwa mereka tidak mempunyai masalah kesehatan sehingga tidak perlu memeriksakan diri ke pelayanan kesehatan.

Dalam memantau konsumsi kapsul wanita prakonsepsi, kader menemukan kendala yaitu wanita prakonsepsi tidak mau minum kapsul karena ada keluhan efek samping kapsul,

Kader tidak dapat mengontrol dengan baik konsumsi kapsul wanita prakonsepsi karena pada saat kader membawakan kapsul kader tidak bertemu dengan wanita prakonsepsi. Wanita prakonsepsi ada yang bekerja dari pagi hingga malam hari sehingga jika kader melakukan kunjungan kader tidak bertemu dengan wanita prakonsepsi.

\section{KESIMPULAN DAN SARAN}

Dari hasil penelitian dan pembahasan tentang peran kader posyandu dalam pada pelayanan terpadu wanita prakonsepsi, maka dapat ditarik kesimpulan sebagai berikut :

1. Dalam mendapatkan informasi tentang warganya yang akan menikah, ada beberapa jalur yang dapat digunakan oleh kader yaitu kader dari TOMA atau pasanagan itu sendiri.

2. Kader menjaring wanita prakonsepsi serta menjadi perantara petugas dimana kader mampu menjaring dan mendampingi wanita prakonsepsi sebanyak 6 orang (86\%).

3. Kader memantau konsumsi kapsul multi zat gizi mikro wanita prakonsepsi dengan mengunjungi dan memberikan kapsul multi zat gizimikro kepada wanita prakosepsi sebanyak 7 kapsul perminggu, kader mengontrol konsumsi kapsul dengan menanyakan jumlah kapsul yang telah dikonsumsi dan kader memberikan motivasi kepada wanita prakonsepsi dan PMO untuk rutin mengkonsumsi kapsul multi zat gizi mikro wanita prakonsepsi. Selama pemantauan 4 minggu, sebanyak 6 orang (86\%) wanita prakonsepsi patuh dan 1 orang (14\%) tidak patuh.

Disarankan agar lebih meningkatkan kepatuhan konsumsi kapsul multi zat gizi mikro wanita prakonsepsi, fungsi dari pengawas minum obat (PMO) perlu ditingkatkan serta Kader harus lebih berperan aktif dalam pemantauan dan pendampingan wanita prakonsepsi.

\section{DAFTAR PUSTAKA}

[1] Kolumnis dan Wartawan Kompas, Rahasia Kecerdasan Anak:Memaksimalkan Perkembangan Otak. Jakarta: Penerbit Buku Kompas, 2010.

[2] BAPPENAS, Rencana Aksi Nasional Pangan dan Gizi 2011-2015. Jakarta: Kementerian Perencanaan Pembangunan Nasioanal, 2010.

[3] Kementerian Kesehatan R.I, Riset Kesehatan Dasar 2010. Jakarta: Badan Litbangkes, 2010.

[4] Kementerian Kesehatan R.I, Riset Kesehatan Dasar 2007. Jakarta: Badan Litbangkes, 2007.

[5] S. Sumarmi, "Pengembangan sistem layanan terpadu pra nikah (laduni) di kabupaten probolinggo, jawa timur," School of Public Health Airlangga University, 2009.

[6] A. Otoluwa, "Pengaruh pemberian suplemen multi zat gizimikro kepada wanita prakonsepsi terhadap pencegahan kerusakan DNA ibu hamil,” Universitas Hasanuddin, 2013.

[7] F. . Trisnawati, A.G. dan Rahayu, "Pelatihan peningkatan kemampuan kader kesehatan dalam penanganan tuberk- 
ulosis (tbc) di wilayah kerja puskesmas gemolong ii sragen," WARTA, vol. 11, no. 2, pp. 150 - 158, 2008.

[8] Sulastyawati. Nataliswati T. \& Nurul Hidayah, "Pengaruh pelatihan promosi kesehatan tentang DHF terhadap peningkatan keterampilan penyuluhan kader kesehatan," Sci. J., 2007.

[9] S. Sarwono, Sosiologi Kesehatan. Yogyakarta: Gajah Mada University Press, 2004.

[10] K. T. Hanna, S. Pramodho, "Profil Kader Kesehatan di Perkotaan, Proyek Kerjasama Perdhaki-PPA," Jakarta, 1990.

[11] Hafess A. Mohammad B.K. Shiekh M.R. Shah S.A.I. \& Jooma R, "Lady health workers programme in Pakistan: callenges, achievements, and the way forward," J Park med Assio, vol. 61, pp. 210-215, 2011.

[12] R. . Helmi, A.F., Thaha, A.R., dan Thaha, "Kepatuhan ibu dalam pemberian taburia pada anak umur 6-24 bulan di Kabupaten pangkep tahun 2011," Universitas Hasanuddin, 2011.

[13] B. Hutabarat, "Pengaruh faktor internal dan eksternal terhadap kepatuhan minum obat penderita kusta di Kabupaten Asahan Tahun 2007," Universitas Sumatera Utara, 2008.

[14] N. Broek, "Anaemia and micronutrient deficiencies: reducing maternal death and disability during pregnancy," $\mathrm{Br}$ Med Bull, vol. 67, pp. 149-160, 2003.

[15] S. . Sipato, "Peran pendampingan kader masyarakat terhadap kepatuhan mengkonsumsi tablet zat besi dan perbaikan hemoglobin ibu hamil di Kelurahan Manongkoki Polongbangkeng Utara Kabupaten Takalar Tahun 2011," Universitas Hasanuddin, 2011.

[16] I. . Mantra, Strategi Penyuluhan Kesehatan Masyarakat. Jakarta: Pusat Penyuluhan Kesehatan Masyarakat, 1997. 